\title{
Isotopic Studies of the Ammonia Decomposition Reaction Using Lithium Imide Catalyst
}

\author{
Thomas J. Wood ${ }^{+*}$, Joshua W. Makepeace ${ }^{\ddagger}$ and William I. F. David ${ }^{\dagger \neq *}$ \\ + ISIS Facility, Rutherford Appleton Laboratory, Harwell Oxford, Didcot, OX11 0QX, UK \\ ₹ Inorganic Chemistry Laboratory, University of Oxford, Oxford, OX1 3QR, UK \\ *Corresponding authors: thomas.wood@stfc.ac.uk, bill.david@stfc.ac.uk
}

\section{ABSTRACT}

Ammonia decomposition using ${ }^{15} \mathrm{~N}$ labelled ammonia was performed over a lithium imide catalyst with mass spectrometry. The results show that all the nitrogen is released from the bulk of the lithium imide catalyst during the ammonia decomposition reaction, but that the decomposition itself occurs at the catalyst surface; they also indicate that lithium imide decomposes ammonia and does not merely act as a promoter to transition metal catalysts.

\section{INTRODUCTION}

Ammonia has significant potential as an energy vector for a future carbon-free economy since it is liquid at room temperature and moderate pressure (10 bar), has a substantial extant infrastructure and contains a large proportion of hydrogen $\left(17.8 \mathrm{wt} \%\right.$ or $\left.121 \mathrm{~kg} \mathrm{H}_{2} \mathrm{~m}^{-3}\right) .^{1,2}$ The energy stored within the ammonia molecule may be released by combustion, with environmentally benign $\mathrm{N}_{2}$ and $\mathrm{H}_{2} \mathrm{O}$ as products, or may be first decomposed to release hydrogen and nitrogen before using the hydrogen within a fuel cell (again with $\mathrm{N}_{2}$ and $\mathrm{H}_{2} \mathrm{O}$ as overall products). ${ }^{3,4,5,6,7}$ The combustion of ammonia also benefits from a partial decomposition into hydrogen and nitrogen since flame propagation properties for internal combustion engines improve with hydrogen/ammonia mixtures compared to ammonia only. ${ }^{8,9}$

It has been shown that sodium/sodium amide and lithium amide-imide can be used as catalysts for the decomposition of ammonia into nitrogen and hydrogen with a catalysis performance that is closely comparable to the state-of-the-art ruthenium catalysts. ${ }^{10,11,12,13}$ Previous isotopic studies using $\mathrm{NH}_{3}$ and $\mathrm{ND}_{3}$ over $\mathrm{NaNH}_{2}$ and $\mathrm{NaND}_{2}$ showed a significant kinetic isotope effect and suggested that the sodium-based catalyst is present as either sodium metal or sodium amide depending on the partial pressure of ammonia. ${ }^{14}$ For lithium amide-imide, however, the lithium amide does not decompose to its elemental constituents, but rather to lithium imide with the concurrent release of ammonia ( $2 \mathrm{LiNH}_{2} \rightarrow \mathrm{Li}_{2} \mathrm{NH}+\mathrm{NH}_{3}$ ) at around $350{ }^{\circ} \mathrm{C}$. This reaction is reversible, but does not involve nitrogen and hydrogen. The question remains, therefore, as to how the lithium amide-imide catalyst decomposes ammonia at temperatures above the stability of lithium amide. A previous in-situ 
neutron powder diffraction study of ammonia decomposition by lithium amide-imide showed that $H-D$ exchange occurred throughout the bulk of the sample when $L_{1+x} N D_{2-x}$ was exposed to $N H_{3}$. However, it remains unclear whether this is as a result of simple proton exchange between amide and imide anions or a bulk exchange of the nitrogen array. ${ }^{13}$

In this article, we describe the use of ${ }^{15} \mathrm{~N}$ labelled ammonia to study the ammonia decomposition reaction over lithium imide with residual gas mass spectrometry. The results give insight into the mechanism for the ammonia decomposition reaction and suggest that the lithium imide is acting as a catalyst in its own right and not merely as a promoter for the transition metal catalysed decomposition of ammonia.

\section{EXPERIMENTAL}

Ammonia decomposition experiments were performed in a cylindrical, nickel-plated, stainless steel reactor with an internal volume of $21.3 \mathrm{~cm}^{3}$. The reactor has an inlet gas pipe running from the reactor lid to around $1 \mathrm{~cm}$ from the base of the reactor. A thermocouple monitored the temperature $5 \mathrm{~mm}$ from the bottom of the reactor. This reactor geometry was chosen in order to avoid any potential problems of catalyst escape or blocking due to the catalyst potentially being liquid under certain conditions. ${ }^{13}$ The composition of the reactor was chosen to be nickel-plated stainless steel because quartz (a more usual reactor composition choice) reacts with lithium amide at elevated temperatures to produce lithium oxide and lithium silicates. ${ }^{15}$ Prior to each experiment, the reactor was treated with flowing $\mathrm{NH}_{3}$ gas (natural isotopic abundance, $99.98 \%$, SIP Analytical) at $500{ }^{\circ} \mathrm{C}$ to ensure that any nitride species in the reactor walls were $M_{x}{ }^{14} N$ not $M_{x}{ }^{15} N$. Flowing gases ( $A r$ or ${ }^{15} \mathrm{NH}_{3}$ ) were regulated by mass flow controllers (HFC-302, Teledyne Hastings Instruments) and the outlet gas flow monitored by a mass flow meter (HFM-300, Teledyne Hastings Instruments) within a custom-designed gas panel, Figure 1. The gas species exiting the reactor were characterised by Quantitative Gas Analysis (QGA) using a Hiden Analytical HPR-20 QIC R\&D mass spectrometer system in histogram mode (MASsoft 7), monitoring peaks from $\mathrm{m} / \mathrm{z}=1$ to $\mathrm{m} / \mathrm{z}=40$ (inclusive).

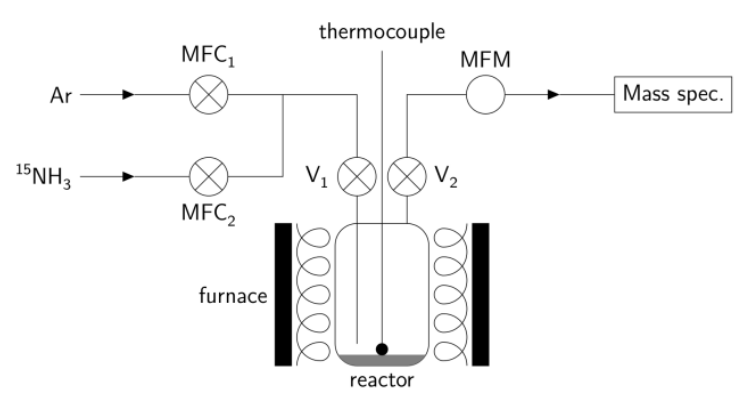

Figure 1: Experimental setup, where the incoming $\mathrm{Ar}$ or ${ }^{15} \mathrm{NH}_{3}$ gas flows are controlled by mass flow controllers ( $M F C_{1}$ and $M^{\prime} C_{2}$ respectively) before entry into the reactor. Valves are located above the reactor inlet and 
outlet $\left(V_{1}\right.$ and $\left.V_{2}\right)$, allowing it to be isolated when evacuating the gas panel upstream. Gas flow out of the reactor is monitored by a mass flow meter (MFM) before analysis via a mass spectrometer.

The isotopic reactions used the following gases: ${ }^{15} \mathrm{NH}_{3}$ (98 atom \% ${ }^{15} \mathrm{~N}$, Sigma-Aldrich) and argon $(99.998 \%, \mathrm{BOC})$. Lithium imide $\left(\mathrm{Li}_{2} \mathrm{NH}\right)$ catalyst was synthesised by the solid state reaction $\left(\mathrm{LiNH}_{2}+\right.$ $\left.\mathrm{Li}_{3} \mathrm{~N} \rightarrow 2 \mathrm{Li}_{2} \mathrm{NH}\right)$ between lithium amide $\left(\mathrm{H}_{2}\right.$ storage grade, Sigma-Aldrich) and lithium nitride $(99.5 \%$, Sigma-Aldrich) at $300^{\circ} \mathrm{C}$ for $12 \mathrm{~h}$.

Typical experiments were performed by loading $0.1 \mathrm{~g}$ of lithium imide into the reactor under an argon atmosphere. The catalyst sample was located underneath the gas inlet pipe. The reactor was heated to around $475^{\circ} \mathrm{C}$ (at $5^{\circ} \mathrm{C} \mathrm{min}-1$ ) under flowing argon gas (25 standard cubic centimetres per minute, sccm) in order to prevent the conversion of lithium imide into lithium amide via the reaction reaction $\mathrm{Li}_{2} \mathrm{NH}+\mathrm{NH}_{3} \rightarrow \mathrm{LiNH}_{2}$. After the temperature had equilibrated, the reactor inlet valve $\left(\mathrm{V}_{1}\right.$, Figure 1) was closed and the rig was evacuated up to $V_{1}$ to $<1$ mbar through mass flow controller $M \mathrm{CC}_{1} .{ }^{15} \mathrm{NH}_{3}$ was subsequently introduced via a second mass flow controller, MFC 2 , and flowed through the reactor at $15 \mathrm{sccm}$ until equilibration of the gas components detected by the mass spectrometer was reached. A control experiment without any lithium imide was also run under the same conditions. The pressure in the reactor was $0.995-1.020$ bar at all times.

Ammonia decomposition sigmoids were obtained using the same reactor, but with a constant flow of $30 \mathrm{sccm}$ of ammonia and initial catalyst mixtures of (i) $0.5 \mathrm{~g}$ lithium amide only, (ii) $0.5 \mathrm{~g}$ lithium amide ground together in pestle and mortar with $0.5 \mathrm{~g}$ iron powder (Alfa Aesar, 325 mesh, 98\%) or (iii) 0.5 g lithium amide ground together with 0.5 g nickel powder (Alfa Aesar, 325 mesh, 99.8\%). Lithium amide was used rather than lithium imide because lithium imide heated under ammonia converts to lithium amide before any ammonia decomposition is observed.

Mass spectrometry data analysis involved fitting each histogram collected to fractions of the following gases: $\mathrm{Ar},{ }^{15} \mathrm{~N}_{2},{ }^{14} \mathrm{~N}^{15} \mathrm{~N},{ }^{14} \mathrm{~N}_{2},{ }^{15} \mathrm{NH}_{3},{ }^{14} \mathrm{NH}_{3}$ and $\mathrm{H}_{2}$. The mass spectrometer was calibrated using pure gas streams of the relevant gases $\left(\mathrm{Ar}, \mathrm{N}_{2}, \mathrm{ND}_{3}, \mathrm{NH}_{3}\right.$ and $\mathrm{H}_{2}$, where the nitrogen-containing species had natural abundance nitrogen), in order to ascertain the fragment peak ratios (isotopologues of nitrogen-containing species were assumed to have identical fragmentation ratios), Table S1. The relative ionization factors (how well the mass spectrometer filament ionizes each gas) were calculated from running 50/50 mixtures of each gas with argon (which itself was given a standardized ionization factor of 1.0).

\section{RESULTS \& DISCUSSION}


The mass-spectrometry calculated gas fractions for the flow out of the blank reactor (nickel-plated reactor without any lithium imide catalyst) are presented in Figure 2. After the inlet gas flow in is switched from argon to ${ }^{15} \mathrm{NH}_{3}$ (at time $=0$ mins), there is a brief period where solely argon is detected, which is due to the residual gas in the reactor, and in the rig between the reactor and the mass spectrometer. Once the argon fraction begins to drop, there is an increase in $\mathrm{H}_{2}$ and ${ }^{14} \mathrm{~N}_{2}$ signals, with the $\mathrm{H}_{2}$ to total $\mathrm{N}_{2}$ ratio being large, peaking at a value of around 18.5 at time $\approx 8$ mins (where the ${ }^{14} \mathrm{~N}_{2}$ signal is at a maximum), before dropping asymptotically to 3 (the value expected for constant ammonia decomposition, $2 \mathrm{NH}_{3} \rightarrow \mathrm{N}_{2}+3 \mathrm{H}_{2}$ ), (see Figure 3). This increase in $\mathrm{H}_{2}$ signal is consistent with partial nitriding of the reactor walls taking place via the reaction $x M+\mathrm{NH}_{3} \rightarrow \mathrm{M}_{x} \mathrm{~N}+$ $1.5 \mathrm{H}_{2}$, where $\mathrm{M}$ is $\mathrm{Ni}$ from the plated reactor or Fe from the stainless steel underneath the nickel plating. Small amounts of ${ }^{14} \mathrm{~N}$ containing $\mathrm{N}_{2}$ species $\left({ }^{14} \mathrm{~N}_{2}\right.$ and $\left.{ }^{14} \mathrm{~N}^{15} \mathrm{~N}\right)$ are released as well as a significant amount of ${ }^{14} \mathrm{NH}_{3}$, which indicate the presence of some ${ }^{14} \mathrm{~N}$ in the walls of the reactor as metal nitride before ${ }^{15} \mathrm{NH}_{3}$ was introduced.

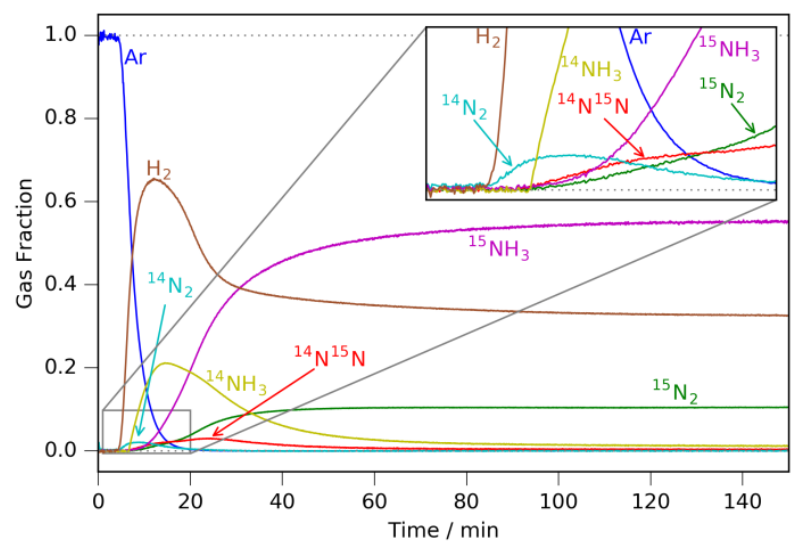

Figure 2: Gas fractions calculated from mass spectrometry for the blank reactor without lithium imide catalyst. The gas flow was switched from argon to ${ }^{15} \mathrm{NH}_{3}$ at time $=0$ mins.

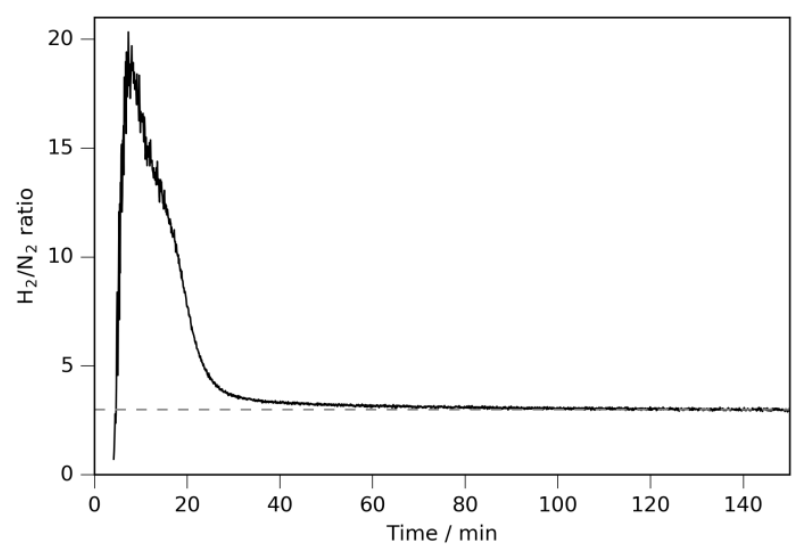


Figure 3: The ratio of $\mathrm{H}_{2}$ to total $\mathrm{N}_{2}\left({ }^{15} \mathrm{~N}_{2}+{ }^{14} \mathrm{~N}^{15} \mathrm{~N}+{ }^{14} \mathrm{~N}_{2}\right)$ for the blank reactor. The values start at the first point that a significant $\mathrm{N}_{2}$ signal is observed (to avoid zero division errors). The dashed line is at $\mathrm{H}_{2} / \mathrm{N}_{2}=3$, the value expected when only ammonia decomposition occurs.

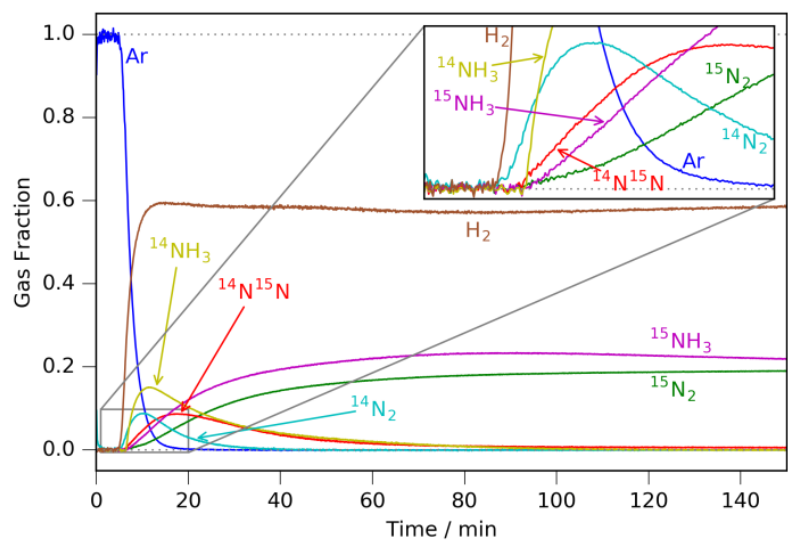

Figure 4: Gas fractions calculated from mass spectrometry for the reactor with lithium imide catalyst. The gas flow was switched from argon to ${ }^{15} \mathrm{NH}_{3}$ at time $=0$ mins.

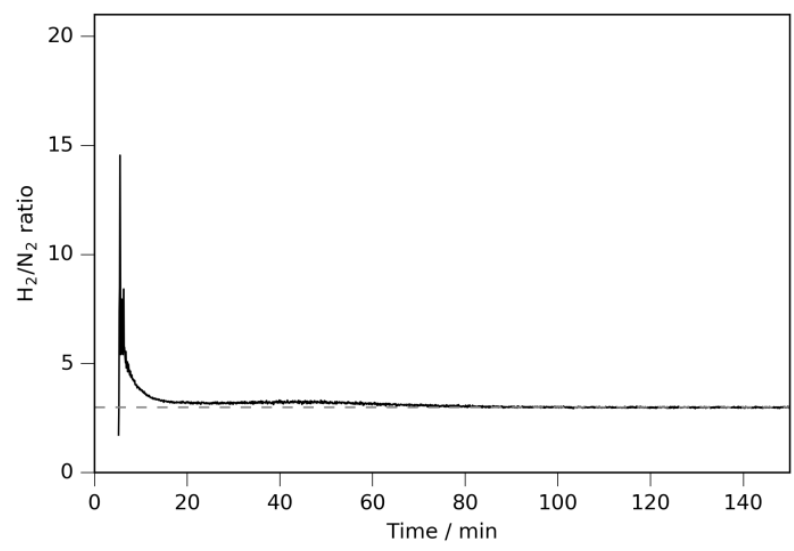

Figure 5: The ratio of $\mathrm{H}_{2}$ to total $\mathrm{N}_{2}\left({ }^{15} \mathrm{~N}_{2}+{ }^{14} \mathrm{~N}^{15} \mathrm{~N}+{ }^{14} \mathrm{~N}_{2}\right)$ for the reactor with $0.1 \mathrm{~g}$ lithium imide catalyst. The values start at the first point that a significant $\mathrm{H}_{2}$ signal is observed (to avoid zero division errors); the datum at $\mathrm{H}_{2} / \mathrm{N}_{2}=14.5$ is a single point. The dashed line is at $\mathrm{H}_{2} / \mathrm{N}_{2}=3$.

The mass-spectrometry calculated gas fractions for the nickel-plated reactor with $0.1 \mathrm{~g}$ of lithium imide catalyst are shown in Figure 4. There is a similar initial period as the one observed in the blank reactor where argon is expelled from the reactor and rig before the $\mathrm{H}_{2}$ and ${ }^{14} \mathrm{~N}_{2}$ signals begin to rise. In contrast to the blank reactor, the $\mathrm{H}_{2}$ to $\mathrm{N}_{2}$ ratio only rises to a value of around 6.5 after time $\approx 6$ mins (there is a single point spike at a value of $\mathrm{H}_{2} / \mathrm{N}_{2}=14.5$, time $=5.5 \mathrm{mins}$ ) before falling, again asymptotically, to a value of around 3. This indicates that there is some nitriding of the metal taking place as before, but the $\mathrm{H}_{2}$ to $\mathrm{N}_{2}$ ratio is decreased, because the ammonia decomposition reaction is 
more prominent. This effect can be seen in the final gas fractions at 150 minutes in each case, where the blank reactor has an ammonia fraction of 0.56 compared to 0.22 when the lithium imide catalyst is present.

It is possible to calculate the amount of ${ }^{14} \mathrm{~N}$ released from the reactor walls or the lithium imide catalyst by integrating the gas fractions of ${ }^{14} \mathrm{~N}$-containing species with respect to time multiplied by the gas flow rate according to equation (1):

$$
V_{i}=\int_{0}^{t} F(t) f_{i}(t) d t
$$

where $V_{i}$ is the volume of species $i, F(t)$ is the flow rate out of the reactor (as measured by the mass flow meter) and $f_{i}(t)$ is the gas fraction of $i$ (as measured by the mass spectrometer). Integrating between $t=0$ mins and $t=150$ mins for both the blank reactor and the reactor with lithium imide catalyst yields the gas volumes shown in Table 1 . The total amount of ${ }^{14} \mathrm{~N}$ released from the reactor walls or lithium imide catalyst can then be calculated by summing the volumes of the ${ }^{14} \mathrm{~N}$-containing species and a value of $4.7(6) \times 10^{-3} \mathrm{~mol}^{14} \mathrm{~N}$ is produced from the blank reactor whereas the reactor with catalyst yielded $7.8(6) \times 10^{-3} \mathrm{~mol}^{14} \mathrm{~N}$. The difference in the amounts of ${ }^{14} \mathrm{~N}$ is $3.1(8) \times 10^{-3} \mathrm{~mol}$, which is equivalent (within experimental uncertainty) to the $3.45(2) \times 10^{-3} \mathrm{~mol}$ of ${ }^{14} \mathrm{~N}$ in the $0.1 \mathrm{~g}$ of lithium imide catalyst. This is strong evidence that the extra ${ }^{14} \mathrm{~N}$ has come from the lithium imide catalyst and that all the ${ }^{14} \mathrm{~N}$ within the catalyst has been released over the course of the ammonia decomposition reaction. It is worth noting that the extra ${ }^{14} \mathrm{~N}$ in the lithium imide (as opposed to the blank) case is released as ${ }^{14} \mathrm{~N}_{2}$ and ${ }^{14} \mathrm{~N}^{15} \mathrm{~N}$, whereas the ${ }^{14} \mathrm{NH}_{3}$ volumes released are approximately equal. This suggests that the same reaction may be responsible for ${ }^{14} \mathrm{NH}_{3}$ release in both cases (i.e. ${ }^{14} \mathrm{NH}_{3}$ is produced by interaction with the reactor walls).

Table 1: Volumes of ${ }^{14} \mathrm{~N}$-containing gas species and total ${ }^{14} \mathrm{~N}$ produced after ${ }^{15} \mathrm{NH}_{3}$ introduced into reactor along with the ${ }^{14} \mathrm{~N}$ contained within the catalyst.

\begin{tabular}{|c|c|c|c|c|c|}
\hline \multirow[b]{2}{*}{ Experiment } & \multicolumn{3}{|c|}{ Volume released $/ \mathrm{cm}^{3}$} & \multirow{2}{*}{$\begin{array}{l}\text { Total }{ }^{14} \mathrm{~N} \text { released } \\
/ 10^{-3} \mathrm{~mol}\end{array}$} & \multirow{2}{*}{$\begin{array}{l}{ }^{14} \mathrm{~N} \text { in catalyst / } \\
10^{-3} \mathrm{~mol}\end{array}$} \\
\hline & ${ }^{14} \mathrm{~N}^{15} \mathrm{~N}$ & ${ }^{14} \mathbf{N}_{2}$ & ${ }^{14} \mathrm{NH}_{3}$ & & \\
\hline Blank reactor & $14(2)$ & $4.3(1.0)$ & 91(13) & $4.7(6)$ & - \\
\hline Reactor $+0.1 \mathrm{~g} \mathrm{Li}_{2} \mathrm{NH}$ & $59(6)$ & $23(4)$ & $86(9)$ & $7.8(6)$ & $3.45(2)$ \\
\hline
\end{tabular}

Additional information about the blank reactor control and the lithium imide catalysed ammonia decomposition reaction can be gained by calculating the fraction of ${ }^{14} \mathrm{~N}$ in the $\mathrm{N}_{2}$ species, denoted $f_{14}$. This quantity is shown in Figure 6(a) for the blank reactor and after an initial period can be fitted to a simple exponential decay with a time constant of $10.58(3)$ minutes, suggesting that a single process is principally responsible for replacing ${ }^{14} \mathrm{~N}$ with ${ }^{15} \mathrm{~N}$ in the $\mathrm{N}_{2}$ signal. Further evidence for 
significant nitriding of the reactor walls taking place can be deduced from the fact that the total $\mathrm{N}_{2}$ signal is stepped, only reaching close to its final value after 30 minutes. This corresponds to the $\mathrm{H}_{2} / \mathrm{N}_{2}$ ratio only reaching values close to 3 after around 30 minutes (see Figure 3 ).

The $f_{14}$ parameter can also be used to compare the ratios of nitrogen isotopologues $\left({ }^{14} \mathrm{~N}_{2},{ }^{14} \mathrm{~N}^{15} \mathrm{~N}\right.$ and ${ }^{15} \mathrm{~N}_{2}$ ) compared with what might be expected if the production of $\mathrm{N}_{2}$ was entirely scrambled (i.e. the likelihood of production of ${ }^{14} \mathrm{~N}_{2},{ }^{14} \mathrm{~N}^{15} \mathrm{~N}$ or ${ }^{15} \mathrm{~N}_{2}$ entirely relies on the proportion of ${ }^{14} \mathrm{~N}$ to ${ }^{15} \mathrm{~N}$ available). The scrambled ratios can be calculated as follows:

$$
\begin{aligned}
& { }^{14} \mathrm{~N}_{2(\text { scram })}=f_{14}^{2} \sum_{i} \mathrm{~N}_{2(i)} \\
& { }^{14} \mathrm{~N}^{15} \mathrm{~N}_{(\text {scram })}=2 f_{14}\left(1-f_{14}\right) \sum_{i} \mathrm{~N}_{2(i)} \\
& { }^{15} \mathrm{~N}_{2(\text { scram })}=\left(1-f_{14}\right)^{2} \sum_{i} \mathrm{~N}_{2(i)}
\end{aligned}
$$

where $\sum_{i} \mathrm{~N}_{2(i)}$ is the total fraction of $\mathrm{N}_{2}$ species $\left({ }^{14} \mathrm{~N}_{2}+{ }^{14} \mathrm{~N}^{15} \mathrm{~N}+{ }^{15} \mathrm{~N}_{2}\right)$. Taking the difference between the measured signals of ${ }^{14} \mathrm{~N}_{2}$ and ${ }^{14} \mathrm{~N}^{15} \mathrm{~N}$ with the signals calculated for the scrambled ratios in the blank reactor yield the results shown in Figure 6(b) (the difference between measured ${ }^{14} \mathrm{~N}_{2}$ signal and calculated scrambled ${ }^{14} \mathrm{~N}_{2}$ is the same as for ${ }^{15} \mathrm{~N}_{2}$ and equal to minus half that of ${ }^{14} \mathrm{~N}^{15} \mathrm{~N}$ by necessity-details can be found in the ESI). These values show that there is a smaller than expected signal for ${ }^{14} \mathrm{~N}^{15} \mathrm{~N}$ (and correspondingly larger than expected ${ }^{14} \mathrm{~N}_{2}$ and ${ }^{15} \mathrm{~N}_{2}$ signals) over the first 20 minutes of the blank reactor experiment, followed by a slightly larger than expected ${ }^{14} \mathrm{~N}^{15} \mathrm{~N}$ signal before an entirely isotopically scrambled signal is reached after 60 minutes.

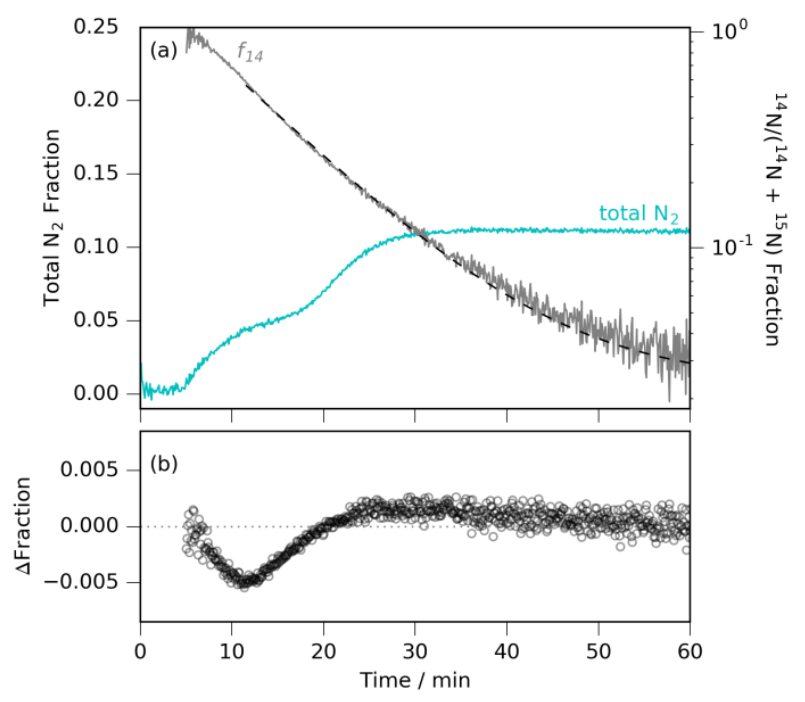

Figure 6: For the blank reactor: (a) the total $\mathrm{N}_{2}$ signal $\left({ }^{14} \mathrm{~N}_{2}+{ }^{14} \mathrm{~N}^{15} \mathrm{~N}+{ }^{15} \mathrm{~N}_{2}\right)$ and the fraction of ${ }^{14} \mathrm{~N}$ within $\mathrm{N}_{2}$ species (exponential decay fit is shown as the black dashed line), (b) the differences between the measured ${ }^{14} \mathrm{~N}^{15} \mathrm{~N}$ signal and its expected value had the $\mathrm{N}_{2}$ species been completely isotopically scrambled. 
This disparity between the measured ratio of nitrogen isotopologues and the calculated ideally scrambled ratio can be explained when the potential reactions for producing nitrogen are considered (it is assumed that $N_{2}$ is produced irreversibly-i.e. it is kinetically, as well as thermodynamically, stable):

$$
\begin{aligned}
& 2 \mathrm{M}_{x} \mathrm{~N} \rightarrow 2 \mathrm{xM}+\mathrm{N}_{2} \\
& 2 \mathrm{NH}_{3} \rightarrow \mathrm{N}_{2}+3 \mathrm{H}_{2} \\
& 2 \mathrm{NH}_{3}+2 \mathrm{M}_{x} \mathrm{~N} \rightarrow 2 \mathrm{xM}+2 \mathrm{~N}_{2}+3 \mathrm{H}_{2}
\end{aligned}
$$

where (5) is metal denitriding, (6) is ammonia decomposition (on the surface of the metal with no interaction with the bulk) and (7) is metal denitriding via ammonia decomposition. The starting conditions (at $t=0$ ) is that any $\mathrm{M}_{\mathrm{x}} \mathrm{N}$ is $\mathrm{M}_{\mathrm{x}}{ }^{14} \mathrm{~N}$ (which is the only possible source of ${ }^{14} \mathrm{~N}$ in the blank reactor experiment) and any ammonia entering the system is ${ }^{15} \mathrm{NH}_{3}$, which means that reactions (5) and (6) must be largely responsible for any $\mathrm{N}_{2}$ production at the start of the reaction since they would produce ${ }^{14} \mathrm{~N}_{2}$ and ${ }^{15} \mathrm{~N}_{2}$ respectively, whereas reaction (7) would produce ${ }^{14} \mathrm{~N}^{15} \mathrm{~N}$, which has a depressed signal compared to that calculated for ideally scrambled. The fact that reaction (5) only produces ${ }^{14} \mathrm{~N}_{2}$ once ${ }^{15} \mathrm{NH}_{3}$ is introduced into the reactor indicates that extant $M x^{14} \mathrm{~N}$ is stable under Ar but not under ${ }^{15} \mathrm{NH}_{3}$. This is presumably because under ${ }^{15} \mathrm{NH}_{3}$ flow there is now a source of nitrogen available to re-nitride any metal (or at least stabilize any reaction intermediate/transition state for reaction (5)). Indeed, after $t=0$, the dominant reaction is metal nitriding according to:

$$
2 x M+2{ }^{15} \mathrm{NH}_{3} \rightarrow 2 \mathrm{M}_{x}^{15} \mathrm{~N}+3 \mathrm{H}_{2}
$$

The dominance of reaction (8) (as shown by the large $\mathrm{H}_{2} / \mathrm{N}_{2}$ ratio in Figure 3) explains the initial suppression of ${ }^{14} \mathrm{~N}^{15} \mathrm{~N}$ and ${ }^{15} \mathrm{~N}_{2}$ release, since the source of ${ }^{15} \mathrm{~N}\left({ }^{15} \mathrm{NH}_{3}\right)$ is being used to nitride the reactor $\left(M_{x}{ }^{15} \mathrm{~N}\right.$ is the only non-gaseous product able to be formed by $\left.{ }^{15} \mathrm{NH}_{3}\right)$. The ${ }^{14} \mathrm{~N}^{15} \mathrm{~N}$ and ${ }^{15} \mathrm{~N}_{2}$ signals are only observed once the $\mathrm{H}_{2} / \mathrm{N}_{2}$ ratio has peaked at $t=7$ mins (see Figures 2 and 3). The reverse of reaction (8) is also possible in these conditions. ${ }^{16}$ Reaction (8) and the reverse reaction along with the following reaction:

$$
{ }^{15} \mathrm{NH}_{3}+\mathrm{Mx}{ }^{14} \mathrm{~N} \rightarrow \mathrm{Mx}{ }^{15} \mathrm{~N}+{ }^{14} \mathrm{NH}_{3}
$$

lead to scrambling of ${ }^{14} \mathrm{~N} /{ }^{15} \mathrm{~N}$ within the metal nitride and scrambling within the ammonia. This scrambling of $\mathrm{M}_{\mathrm{x}} \mathrm{N}$ and $\mathrm{NH}_{3}$ and the progressive removal of ${ }^{14} \mathrm{~N}$ from the system means that, after longer time periods, reactions (5) and (6) tend to produce scrambled $N_{2}$, hence the trend of the measured $\mathrm{N}_{2}$ signals towards being ideally scrambled. 


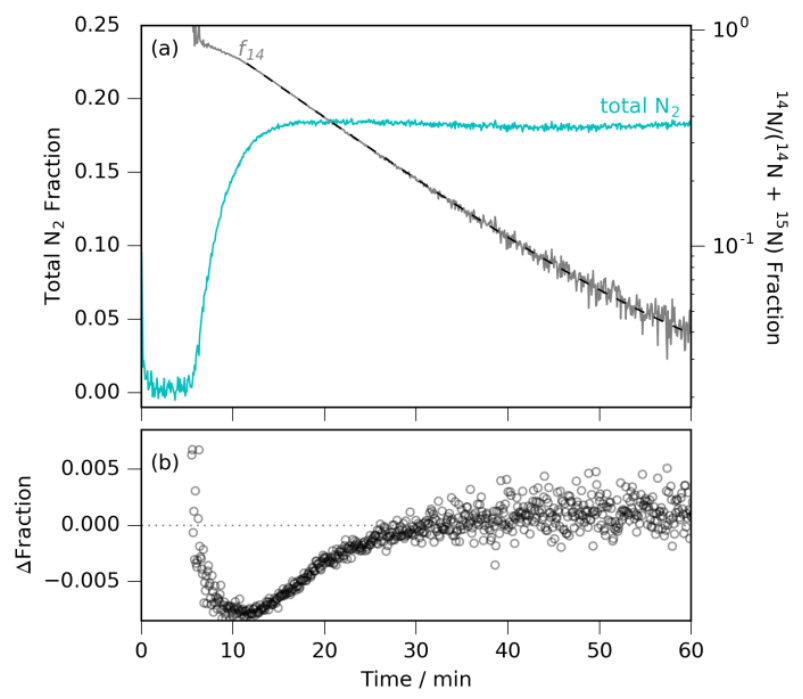

Figure 7: For the reactor with $0.1 \mathrm{~g} \mathrm{Li} 2 \mathrm{NH}$ : (a) the total $\mathrm{N}_{2}$ signal $\left({ }^{14} \mathrm{~N}_{2}+{ }^{14} \mathrm{~N}^{15} \mathrm{~N}+{ }^{15} \mathrm{~N}_{2}\right)$ and the fraction of ${ }^{14} \mathrm{~N}$ within $\mathrm{N}_{2}$ species (exponential decay fit is shown as the black dashed line), (b) the differences between the measured ${ }^{14} \mathrm{~N}^{15} \mathrm{~N}$ signal and its expected value had the $\mathrm{N}_{2}$ species been completely isotopically scrambled.

Similar calculations for $f_{14}$ were performed for the lithium imide experiment, Figure $7(\mathrm{a})$, with the $f_{14}$ value again able to be fitted to a simple exponential decay with a time constant of 14.35(2) minutes. This time constant is longer than the blank control due to the larger amount of ${ }^{14} \mathrm{~N}$ released over the course of the experiment under a similar flow. A similar trend emerges for the difference between the $\mathrm{N}_{2}$ isotopologue signals and the ideally scrambled, Figure $7(\mathrm{~b})$, but with the reduction in ${ }^{14} \mathrm{~N}^{15} \mathrm{~N}$ being larger and more prolonged than for the blank control.

This increase in the disparity of the measured nitrogen signals and the calculated ideally scrambled nitrogen fractions means that the lithium imide catalyst must be contributing ${ }^{14} \mathrm{~N}_{2}$ as well as the blank reactor. It is known that the lithium imide reacts with ammonia to produce lithium amide via a reversible reaction:

$$
\mathrm{Li}_{2} \mathrm{NH}+\mathrm{NH}_{3} \leftrightharpoons 2 \mathrm{LiNH}_{2}
$$

where $\mathrm{Li}_{2} \mathrm{NH}$ and $\mathrm{LiNH}_{2}$ are end members of a solid solution $\mathrm{Li}_{1+x} \mathrm{NH}_{2-\times .}{ }^{12,17}$ However, reaction (10) leads to the scrambling of nitrogen within the lithium amide/imide and is not a mechanism for decomposing ammonia. Given that there is less ${ }^{14} \mathrm{~N}^{15} \mathrm{~N}$ than might be expected initially, the ammonia presumably decomposes on the surface of the lithium imide (since interaction with the bulk leads to scrambling of the $\mathrm{N}_{2}$ species).

It is proposed that the lithium imide itself decomposes in the presence of ammonia to form some lithium-rich species, which then reacts with ammonia to re-form the lithium imide. Lithium nitride hydride $\left(\mathrm{Li}_{4} \mathrm{NH}\right)$ is a known decomposition product of lithium imide (along with hydrogen and 
nitrogen) and forms a solid solution with lithium imide. ${ }^{18,19}$ Of the lithium-nitrogen-hydrogen species known, $\mathrm{Li}_{4} \mathrm{NH}$ is the most probable candidate for the lithium-rich species, according to the following reactions:

$$
\begin{aligned}
& 2 \mathrm{Li}_{2} \mathrm{NH} \rightarrow \mathrm{Li}_{4} \mathrm{NH}+1 / 2 \mathrm{~N}_{2}+1 / 2 \mathrm{H}_{2} \\
& \mathrm{Li}_{4} \mathrm{NH}+\mathrm{NH}_{3} \rightarrow 2 \mathrm{Li}_{2} \mathrm{NH}+\mathrm{H}_{2}
\end{aligned}
$$

Adding reactions (11) and (12) together gives ammonia decomposition into nitrogen and hydrogen mediated by the lithium imide/lithium nitride hydride pairing. Within this scheme, the only source of nitrogen gas is from reaction (11), which would mean an initial increase in ${ }^{14} \mathrm{~N}_{2}$ release from $\mathrm{Li}_{2}{ }^{14} \mathrm{NH}$. This is consistent with the flattening of $f_{14}$ until $t=11$ minutes after which it follows a simple exponential decay. This flattening, which is exaggerated by the ammonia consumption of reaction (10) causing lower flow, is not seen in the case of the blank reactor. This move from a flattened decay into a simple exponential decay coincides with the peak difference between the measured $\mathrm{N}_{2}$ isotopologue signals and the calculated ideally scrambled fractions. In reality, the scheme presented in reactions (11) and (12) must be more complex, since reaction (11) has not been observed under argon at the temperatures at which ammonia decomposition occurs. Therefore the lithium-rich intermediate (here denoted $\mathrm{Li}_{4} \mathrm{NH}$ ) must be stabilized by the presence of ammonia. The fact that no lithium-rich phase has been observed in in-situ neutron powder diffraction experiments ${ }^{13}$ indicates that if it exists as an intermediate, it would be (i) short-lived (i.e. a reactive intermediate, which would be expected, given the presence of ammonia), (ii) amorphous, (iii) present at the surface of the catalyst only (i.e. in low overall concentration), or a combination of these. Given that $\mathrm{Li}_{4} \mathrm{NH}$ forms a solid solution with $\mathrm{Li}_{2} \mathrm{NH}$ and that the catalyst is present mostly as a solid solution between $\mathrm{Li}_{2} \mathrm{NH}$ and $\mathrm{LiNH}_{2}\left(\mathrm{Li}_{1+\mathrm{x}} \mathrm{NH}_{2-\mathrm{x}}\right),{ }^{13}$ the most likely mechanism for ${ }^{14} \mathrm{~N} /{ }^{15} \mathrm{~N}$ bulk exchange is via anion exchange within the bulk solid solution. This would explain the release of all the ${ }^{14} \mathrm{~N}$ from the lithium imide over the course of the experiment.

The lithium-rich intermediate has also been proposed to be a ternary lithium-transition metal nitride, for example, $\mathrm{Li}_{3} \mathrm{FeN}_{2}$ or $\mathrm{LiNiN} / \mathrm{Li}_{5} \mathrm{Ni}_{3} \mathrm{~N}_{3}$ in this case. ${ }^{11,20}$ In these cases, the ammonia decomposition would proceed via reactions analogous to (11) and (12) with the lithium nitride hydride replaced by the relevant ternary nitride. While there is no in-situ evidence of these phases, it would be expected that if they were short-lived intermediates in the reaction, then a mixture of lithium imide with iron or nickel powder would give better performance for decomposing ammonia than the lithium imide alone. The conversion of ammonia to nitrogen and hydrogen values for lithium amide mixed with iron or nickel powder are shown in Figure 8. The slight difference in sigmoid shape for the nickel plus lithium amide case indicates that the metal interacts with the lithium amide. It is clear, however, that there is no large enhancement in ammonia decomposition 
except for slightly better conversions at temperatures below $450{ }^{\circ} \mathrm{C}$ for the nickel case. Given that the ${ }^{15} \mathrm{NH}_{3}$ studies were performed above $450{ }^{\circ} \mathrm{C}$, this indicates that the lithium-rich phase proposed in reaction (11) is unlikely to be a ternary nitride.

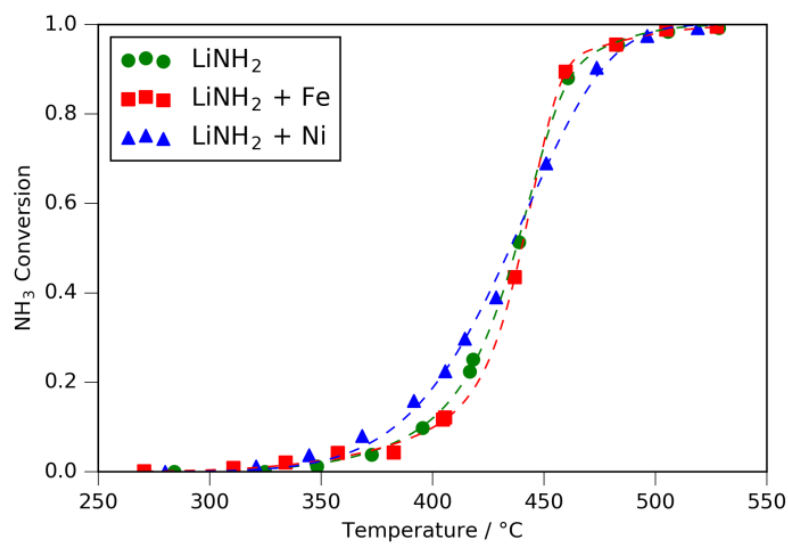

Figure 8: Ammonia decomposition as a function of temperature under $30 \mathrm{sccm} \mathrm{NH}$ for $0.5 \mathrm{~g}$ lithium amide (green circles), $0.5 \mathrm{~g}$ lithium amide ground together with $0.5 \mathrm{~g}$ iron powder (red squares) or $0.5 \mathrm{~g}$ lithium amide ground together with nickel powder (blue triangles). The dashed lines indicate fits based on a Gompertz function (see ESI for more details).

\section{CONCLUSIONS}

Ammonia decomposition using ${ }^{15} \mathrm{~N}$ labelled ammonia shows that the entirety of the lithium imide is involved in nitrogen exchange. The mechanism is proposed to be via lithium imide decomposition to a lithium-rich phase (probably lithium nitride hydride) at the surface, which is consistent with the proportions of the $\mathrm{N}_{2}$ isotopologues released. Addition of transition metal (Fe or $\mathrm{Ni}$ ) powders shows no marked enhancement in ammonia decomposition which suggests that the lithium imide decomposes ammonia independently of transition metals and that the proposed lithium-rich intermediate is not a ternary lithium transition metal nitride.

\section{ASSOCIATED CONTENT}

\section{Electronic Supporting Information (ESI)}

Data fitting procedures.

\section{AUTHOR INFORMATION}

Corresponding Authors

thomas.wood@stfc.ac.uk; bill.david@stfc.ac.uk

\section{Funding Sources}

This work was financially supported by an EPSRC grant (EP/M014371/1). 


\section{Notes}

The authors declare no competing financial interest

\section{Acknowledgments}

The authors acknowledge the technical assistance of James Taylor for laboratory management. JWM acknowledges St John's College, University of Oxford for financial support.

\section{REFERENCES}

(1) L. Green Jr., An ammonia energy vector for the hydrogen economy, Int. J. Hydrogen Energy, 1982, 7, 355-359.

(2) W. Avery, A role for ammonia in the hydrogen economy, Int. J. Hydrogen Energy, 1988, 13, 761-773.

(3) Dispositifs pour alimenter des moteurs à combustion interne avec des mélanges d'ammoniac, d'hydrogène et d'azote préparés en partant d'ammoniac, Fr. Pat. 802,905, 1936.

(4) K. Kordesch, J. Gsellmann, M. Cifrain, S. Voss, V. Hacker, R. R. Aronsson, C. Fabjan, T. Hejze and J. Daniel-Ivad, Intermittent use of a low-cost alkaline fuel cell-hybrid system for electric vehicles, J. Power Sources, 1999, 80, 190-197.

(5) K. Kordesch, V. Hacker, J. Gsellmann, M. Cifrain, G. Faleschini, P. Enzinger, R. Fankhauser, M. Ortner, M. Muhr and R. R. Aronsson, Alkaline fuel cells applications, J. Power Sources, 2000, 86, 162-165.

(6) M. Cifrain and K. Kordesch, Advances, aging mechanism and lifetime in AFCs with circulating electrolytes, J. Power Sources, 2004, 127, 234-242.

(7) T. Hejze, J. O. Besenhard, K. Kordesch, M. Cifrain and R. R. Aronsson, Current status of combined systems using alkaline fuel cells and ammonia as a hydrogen carrier, J. Power Sources, 2008, 176, 490-493.

(8) M. Comotti and S. Frigo, Hydrogen generation system for ammonia-hydrogen fuelled internal combustion engines, Int. J. Hydrogen Energy, 2015, 40, 10673-10686.

(9) S. Sasaki and J. Sarlashkar, Internal combustion engine with ammonia fuel, U. S. Patent No. 8,166,926, 2012.

(10) W. I. F. David, J. W. Makepeace, S. K. Callear, H. M. A. Hunter, J. D. Taylor, T. J. Wood and M. O. Jones, Hydrogen Production from Ammonia using Sodium Amide, J. Am. Chem. Soc., 2014, 136, 13082-13085.

(11) J. Guo, P. Wang, G. Wu, A. Wu, D. Hu, Z. Xiong, J. Wang, P. Yu, F. Chang, Z. Chen and P. Chen, Lithium Imide Synergy with 3d Transition-Metal Nitrides Leading to Unprecedented Catalytic Activities for Ammonia Decomposition, Angew. Chem. Int. Ed., 2015, 54, 2950-2954.

(12) J. Guo, F. Chang, P. Wang, D. Hu, P. Yu, G. Wu, Z. Xiong and P. Chen, Highly Active MnN-Li ${ }_{2} \mathrm{NH}$ Composite Catalyst for Producing $\mathrm{CO}_{x}$-Free Hydrogen, ACS Catal., 2015, 5, 2708-2713.

(13) J. W. Makepeace, T. J. Wood, H. M. A. Hunter, M. O. Jones and W. I. F. David, Ammonia decomposition catalysis using non-stoichiometric lithium imide, Chem. Sci., 2015, 6, 38053815.

(14) T. J. Wood, J. W. Makepeace, H. M. A. Hunter, M. O. Jones and W. I. F. David, Isotopic studies of the ammonia decomposition reaction mediated by sodium amide, Phys. Chem. Chem. Phys., 2015, 17, 22999-23006.

(15) J. W. Makepeace, H. M. A. Hunter, T. J. Wood, R. I. Smith, C. A. Murray and W. I. F. David, Faraday Discuss., 2016, 188, 525-544.

(16) K. Tamaru, Acc. Chem. Res., 1988, 21, 88-94. 
(17) W. I. F. David, M. O. Jones, D. H. Gregory, C. M. Jewell, S. R. Johnson, A. Walton and P. P. Edwards, A Mechanism for Non-stoichiometry in the Lithium Amide/Lithium Imide Hydrogen Storage Reaction, J. Am. Chem. Soc., 2007, 129, 1594-1601.

(18) R. Marx, Reindarstellung und Kristallstruktur von Lithiumnitridhydrid, $\mathrm{Li}_{4} \mathrm{NH}, \mathrm{Li}_{4} \mathrm{ND}, \mathrm{Z}$. Anorg. Allg. Chem., 1997, 623, 1912-1916.

(19) J. Zhang and Y. H. Hu, Intermediate species and kinetics of lithium imide decomposition, Int. J. Hydrogen Energy, 2012, 37, 10467-10472.

(20) P. Wang, J. Guo, Z. Xiong, G. Wu, J. Wang and P. Chen, The interactions of $\mathrm{Li}_{3} \mathrm{FeN}_{2}$ with $\mathrm{H}_{2}$ and $\mathrm{NH}_{3}$, Int. J. Hydrogen Energy, 2016, 41, 14171-14177. 